\title{
COMUNICADO
}

\section{Detecção molecular de fitoplasmas em plantas do gênero Celosia com malformação das folhas.}

\author{
Bárbara Eckstein ; Ivan Paulo Bedendo
}

ESALQ-USP, Setor de Fitopatologia, C.P. 09, 13418-900, Piracicaba, SP.

Autor para correspondência: Ivan Paulo Bedendo - E-mail ipbedend@esalq.usp.br

Data de chegada: 14/11/2008. Aceito para publicação em: 15/06/2008.

As plantas ornamentais conhecidas por crista-de-galo (Celosia argentea $\mathrm{L}$.) e pluma-de-flamingo (Celosia spicata L.) são encontradas crescendo espontaneamente em logradouros públicos, além de serem usadas comercialmente na composição de jardins. Plantas do gênero Celosia são provavelmente originárias do continente africano e asiático (In: Lost Crops of África, v.2, 1 ed., p.92-103, 2006) e são pouco exigentes quanto aos aspectos relacionados à nutrição, fitossanidade $\mathrm{e}$ tratos culturais.

Em Piracicaba (SP) têm sido observadas alterações na parte aérea de plantas de ambas as espécies, as quais sugerem a ocorrência de infecção por fitoplasmas. Entre os sintomas, os mais comuns se expressam pelo aparecimento de deformação e redução foliar acentuada, superbrotamento de ramos laterais (Figura 1) e enfezamento da planta, além de filodia. Fitoplasmas são procariotos sem parede celular e habitantes, principalmente, do floema, os quais estão associados a centenas de doenças de plantas, incluindo entre elas várias espécies ornamentais. Este trabalho visou à detecção molecular de fitoplasmas em duas espécies do gênero Celosia, buscando demonstrar a presença destes agentes em plantas doentes.

Plantas foram coletadas no campus da ESALQ/USP e em logradouros públicos. Para cada uma das espécies foram amostradas dez plantas sintomáticas e duas assintomáticas. O DNA total foi extraído e usado como modelo nas reações de duplo PCR, com os primers P1/Tint (Smart et al., Applied and Environmental Microbiology, v.62, p.2988-2993, 1996) e R16F2n/16R2 (Gundersen \& Lee, Phytopathologia Mediterrânea, v.35, p.144-151. 1996). As reações, condições de duplo PCR e análise de eletroforese seguiram protocolo de Lee et al. (International Journal of Systematic Bacteriology, v.48, p.1153-1169, 1998), sendo os produtos amplificados corados com Sybr safe ${ }^{\circledR}$ (Invitrogen) e visualizados em transiluminador de luz ultravioleta.

A presença de fitoplasmas foi detectada em $60 \%$ das amostras sintomáticas de C. argentea e em $50 \%$ de C. spicata, através da amplificação de fragmentos genômicos de 1,2 kb. Amplificações de $1,2 \mathrm{~kb}$ também foram obtidas a partir do DNA de plantas de vinca (Catharanthus roseus L.) infectadas por fitoplasma e usadas como controle positivo. No entanto, nenhuma amplificação ocorreu para o DNA extraído de plantas assintomáticas do gênero Celosia. Embora a técnica de duplo PCR seja considerada sensível, não é rara a ocorrência de resultados negativos para plantas que exibem sintomas típicos de infecção por fitoplasmas. Os fatores responsáveis pelo falso negativo nas reações de amplificação podem estar relacionados à baixa concentração e/ou distribuição irregular de fitoplasmas nos tecidos, justificando, possivelmente, a não detecção de fitoplasmas em amostras com sintomas.

A ocorrência de fitoplasmas em plantas da espécie $C$. argentea já foi relatada em outras partes do mundo, porém os sintomas descritos (Tanne et al., Hort Science, v.35, p.1103-1106, 2000; Babaie et al., Journal of Phytopathology, v.155, p.368-372, 2007) diferem parcialmente daqueles observados nas plantas coletadas neste trabalho. No presente caso, as plantas exibiam, predominantemente, sintomas de deformação e redução de tamanho foliar, no entanto a presença de leve amarelecimento foliar foi muito pouco freqüente. Em contraste, para as plantas analisadas em outras partes do mundo, o amarelecimento foi constantemente descrito, porém não houve relato de deformação e redução foliar. No Brasil, através de microscopia eletrônica, fitoplasmas foram encontrados em plantas de crista-degalo apresentando superbrotamento, coletadas em Minas Gerais, na década de 90 (Kitajima, Revisão Anual de Patologia de Plantas, v.2, p.153-174, 1994). A descrição dos sintomas, neste caso, ficou restrita à proliferação de ramos novos, anomalia também constatada nas plantas coletadas em Piracicaba, neste estudo. No presente trabalho, a detecção molecular de fitoplasmas nas plantas confirma os achados anteriores da microscopia, evidenciando a associação destes agentes com as plantas do gênero Celosia portadoras da anomalia.

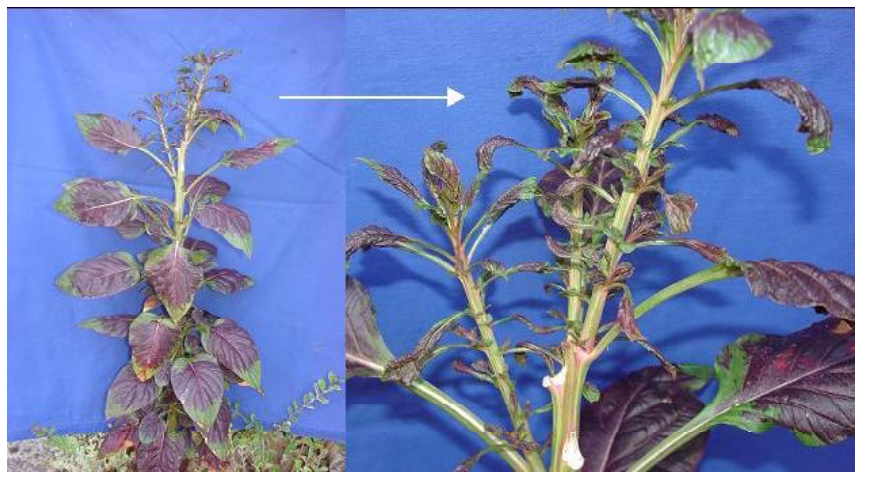

Figura 1. Planta de Celosia spicata com superbrotamento de ramos, redução e deformação foliar. 